\title{
Costs and benefits: Scholarship students' reflective accounts of attending an elite secondary school
}

Jennifer Feldman, Jennifer Wallace

Situated within the context of elite education, the empirical focus of this article is on the reflective accounts of former scholarship students from historically disadvantaged communities who attended elite secondary schools in South Africa. Drawing on studies of scholarship students in educational institutes, the article discusses the costs and benefits, as narrated by the students, of their experiences of elite schooling. While there exists a growing body of literature on elite education globally, there is limited research on elite schools in South Africa and scholarship students within these institutions. Thus, the key contribution of the article is the discussion provided on scholarship students in elite schools in South Africa and their experiences of assimilating into the incongruent terrain of the elite school context.

Keywords: South African schooling; elite schools; scholarship programmes; marginalised students

\section{Introduction}

The offering of scholarship ${ }^{1}$ opportunities to promising students from disadvantaged backgrounds is prevalent both internationally and within the South African school context. Scholarships have become an accepted and even praise-worthy practice at most elite ${ }^{2}$ schools

\footnotetext{
${ }^{1}$ Although in literature the terms 'scholarship' and 'bursary' are sometimes used interchangeably, this article uses the term 'scholarship' as this is the term used by the donor foundations for the financial aid provided for the students.

${ }^{2}$ For the purposes of this article, and drawing on international literature, affluent public and private schools will be described as elite.
} 
and the offer of an opportunity to receive a quality education is generally touted as the panacea for accessing further educational opportunities and ultimately professional employment, especially for students from disadvantaged backgrounds.

Situated within the context of elite education and adopting a postcolonial approach that highlights issues of culture, identity and language, the empirical focus of this article is on the reflective accounts of former scholarship students from historically disadvantaged communities who attended elite secondary schools in South Africa. Drawing on the interview data of twenty scholarship students, the article responds to the following research question: What do the accounts of scholarship students reveal about accepting the gift of a scholarship to attend an elite South African secondary school? The key contribution of the article is the discussion provided on scholarship recipients in relation to secondary schooling. While there exists a growing body of literature on international elite schools and higher education institutions, there is limited research on elite schools in South Africa, as well as on marginalised students who enter these institutions, such as the scholarship students in this study. Furthermore, the limited research that does exist, tends to highlight the schools' perspectives rather than the voices and experiences of the students.

The article begins by providing a brief background on schooling in post-apartheid South Africa and a discussion on elite schools and scholarship programmes. Following this, the article outlines the research methodology. The article then moves to the main discussion and presentation of the study findings on the costs and benefits, as described by the students, of attending an elite secondary school as scholarship recipients. The article concludes by suggesting that for the students in the study, the offer of a scholarship to attend an elite school enabled many opportunities, however, the experience also involved unintended or unanticipated consequences for the scholarship recipients and their families. These 
opportunities and consequences may be viewed as the costs and benefits of accepting a scholarship to attend an elite school.

\section{South African schooling post-apartheid}

Almost a quarter of a century after the introduction of democracy in 1994, South Africa is still recognised as "the most unequal country in the world ... [as a result of] the enduring legacy of apartheid" (The World Bank, 2018, p. 120). One of the dimensions of this inequality is that there exists, in effect, a two-tiered system of education in post-apartheid South Africa, with a persistent gap that is growing ever wider between poorly-functioning, under-resourced schools on the one hand, and high-functioning, well-resourced schools on the other (see for example Bloch, 2009; Hofmeyr \& Govender, 2015; Spaull, 2013; Taylor et al., 2008). Before 1994 the wealthier state and independent schools were predominantly (if not exclusively) white, with all of the benefits of apartheid that were afforded to them. While there have been positive moves towards racial equity in the sense that the demographics of our schools have changed in the post-apartheid years, this has not translated into overall equal educational opportunity nor adequacy.

As a result of the generally poor standard of education in schools within South Africa, many parents seek alternative educational opportunities for their children in the hopes of achieving a better future through the promise of upward social mobility. Every day thousands of young school-going students, identifiable by the multitude of school uniforms that can be seen at bus stops, taxi ranks and train stations, travel across the urban city in order to access quality education (Fataar, 2015). The belief that schools elsewhere offer individualised attention, a wide-ranging programme of cultural and sporting activities, as well as the possibility that these schools offer a shield from the social challenges faced in poorer communities such as drug and alcohol abuse and the threat of physical violence, is part of the 
decision-making process of parents and youth in their choice of schools (Soudien, 2008). In essence, what parents seek for their children by having them travel to 'better schools' are the same opportunities that are afforded the middle- and upper-classes, including preparation for higher education (Geyer \& Walton, 2015). Or, in Fataar's (2007) words, because "they regard them [these schools] as crucial for cultivating the necessary aspirant dispositions that will allow entry into formal middle-class employment and lifestyles." (p. 22)

It must, however, be noted that these decisions are not without their challenges. For example, as Soudien (2007) points out, black children who choose to go to schools outside of townships ${ }^{3}$ are making a conscious and visible break with the past, and as such, may become separated both culturally and spatially from those with whom they grew up. They have to explain to their friends why they have chosen to do this, and run the risk of being called 'sellouts'. Often the students who travel to schools outside their living area are seen as betraying the community where they grew up and still live. Further, research on the experiences of these students within elite schools strongly shows that what is required from these students, upon entering the elite school environment, is a high degree of assimilation into a predominantly white, middle-class culture (see for example Dolby, 2001; Epstein, 2014; Lemon \& BattersbyLennard, 2011; Soudien, 2012). However, at the same time students who choose to travel to schools that they perceive as better than their local school are often able to reap the benefits of the sacrifices they make within this choice. This is illustrated in Fataar's (2015) story of Layla, a teenager who travels daily from her home in a township to attend a formerly white school located near Cape Town's city centre:

\footnotetext{
${ }^{3}$ The term 'townships' with the South African context refers to an area that is usually underdeveloped living area that is built on the periphery of towns and cities.
} 
What was clear in Layla's mediations of her school environment was her ability to figure out what the discourses of acceptability were at the school, and how she had to insert herself into them in order to maximise opportunities for success. Her translocal investments paid off handsomely. Not only did she achieve excellent school results, but she also accessed valuable resources and opportunities that enabled her to acquire the educational and cultural capital necessary for the mobile middle-class lifestyles that she coveted. (pp. 112-113)

Fataar (2015) concludes: "While the hegemonic culture of the city schools positions incoming students like Layla for assimilation, the way they [the students] master the school environment indicates active agency by these mobile youths." (p. 113) In other words, these young people make a conscious decision to access the benefits offered by schools that are seen to offer quality education.

\section{Elite South African schooling}

In the South African context, elite public and private schools are mostly modelled on the British public schooling system. As such this system has had a significant influence on both the external organisational characteristics, as well as on the less visible yet pervasive 'hidden curriculum' of these schools - what Giroux (1983) refers to as the "dispositions, structure and modes of knowledge, pedagogic relationships, and the informal culture that make up the daily character of the school" (p. 63). Most of the elite schools in South Africa are identified as providing the type of capital that is of high symbolic value, such as access to quality learning opportunities, effective educational management and organisational structures, excellent facilities, as well as a wide range of resources, amongst other advantages. In addition, all of these schools charge high school fees relative to the average school fees in the country, making this form of schooling mostly only accessible to the middle and upper class in South Africa. 
With the advent of post-apartheid democratic South Africa, the demographics within many schools shifted. However, within the elite school sector, given the school fees charged at these schools, many such South African schools have struggled to become more representative of the country's demographics. Thus, faced with the vast economic inequalities within this country, many elite schools are recognising the need to find ways to reach out into the student community beyond their 'walls'.

\section{Scholarship programmes}

One such way for these elite schools to reach out beyond their privileged space is through their support of programmes that invite talented students from disadvantaged communities to apply for a scholarship to attend a school that they otherwise might not have had the economic means to attend. It is generally acknowledged that these scholarship programmes are primarily aimed at supporting and developing the students academically in order for them to gain access to higher education. Thus, as an integral part of the usually fairly stringent application and selection process for these scholarships, in addition to proven financial need, potential candidates must demonstrate 'academic potential' by completing Mathematics and English assessments as well as participate in an interview.

Before moving on to a presentation of the data from the study, the next section provides a discussion on the relevant literature, both internationally and within the South African context, in relation to elite education and marginalised students within these institutions.

\section{Marginalised students in elite education institutions}


There are a number of studies that discuss elite education institutions, and some of these include the experiences of marginalised ${ }^{4}$ students within these educational settings. A contemporary international project titled Elite Independent Schools in Globalising Circumstances (20102014), a multi-sited ethnographic project conducted over a five-year period, provided a particularly helpful base for the article research on elite schools. The project was conducted in seven schools located in different countries, including one in South Africa. ${ }^{5}$ Although there are significant differences between this comprehensive study and the study that was conducted for this article ${ }^{6}$ the research project generated multiple articles that were helpful in understanding contemporary elite schooling.

Discussing the specific experiences of marginalised students in elite institutions, three additional studies conducted in America, Horvat and Antonio (1999), Kuriloff and Reichert (2003) and Kramer (2008), are of interest. Horvat and Antonio's (1999) study, that focused on the experiences of six African American senior students in a predominantly white elite independent school, note that the participants in their study mostly felt that it was worth assimilating or changing to fit into the elite school context as it enabled them to access "a superior academic education and a virtual entrance ticket into a selective four-year college.” To emphasise this point, the authors include a quote by the school's (African American) chef: "It's a straight shot from college from here. It's like a straight, a slingshot from here straight to college. Good colleges. Straight shot. With not a doubt.” (p. 337)

\footnotetext{
${ }^{4}$ By marginalised students we refer to students who find themselves in the minority group within a social context as a consequence of their classed, racialised, cultural, religious or gendered identities (Mills \& Gale, 2010).

5 The other countries included in the project are Australia, Barbados, England, Hong Kong, India, and Singapore.

${ }^{6}$ In contrast to a multi-sited, ethnographic approach that focuses predominantly upon the schools and their responses, the focus of this study is on student experiences in schools located in a single country, using an interview-based, narrative research methodology approach.
} 
Likewise, Kuriloff and Reichert's (2003) study, that focused on low-income students attending an elite boys-only school, note that for the boys in the study the sacrifices that they needed to make, which they describe as "mastering 'a drill' that included hard work, unwavering commitment, a will to win, a cool style, and self-knowledge as learners" (p. 751), were deemed to be worthwhile as they felt that ultimately, "all boys at Haverford have a bright future” (p. 767). Similarly, Kramer's (2008) study that presents a discussion on a programme that was developed by a non-profit organisation to prepare marginalised students for the challenges of an elite schooling environment, describes how the students in his study chose to integrate into, "wealthy, predominantly White schools in an attempt to gain social mobility" (p. 287) despite a significant measure of assimilation that was required.

Within the South African schooling context, three studies that focus on the experiences of scholarship students in elite public and independent South African high schools are relevant. Simpson's (2012) Masters Dissertation considers the topic of marginalised students through the lens of adolescent identity formation. Her findings show that the adjustments faced by historically disadvantaged scholarship students include "becoming a part of new cultures, the first being of the dominant white culture, and secondly that of the school culture" (p. 70). Geyer and Walton's (2015) article focuses on the theme of inclusion in relation to the awarding of scholarships to talented and deserving students from disadvantaged backgrounds in South Africa. Geyer and Walton (2015) point out the "extent to which scholarship programmes are essentially assimilationist endeavours" and assert that part of the 'fitting in' requires students to navigate the socioeconomic differences that they encounter, whilst at the same time conforming to the norms and expectations of the elite school context (p. 339). This may, according to Slee (2011) involve the students assuming an "invisible presence" by being reserved and quiet, and assimilating into the dominant culture of the school (p. 107). As such, the study notes that while there are benefits for scholarship recipients attending an elite school, 
there is scope for research that provides a deeper understanding of the experiences of the scholarship students and the possible costs involved.

The third South African study by Kenway and Fahey (2015), which is part of the multisited ethnographic project previously mentioned, provides a discussion on what they refer to as 'privileged benefaction' in the form of the provision of scholarships, within two elite girls' schools - one in South Africa and one in England. In the article, Kenway and Fahey (2015) highlight the complexities of this practice, with its accompanying moral dilemmas and power politics. The article discussion uses the notion of 'the gift' as its analytical lens and provides a broad overview of the different manifestations of, and justifications for, the practice of giftgiving as a form of privileged benefaction. The article concludes that the provision of scholarships to previously disadvantaged candidates, in the form of a 'gift', is a far more complex practice than perhaps initially recognised or acknowledged by all stakeholders.

In addition to studies on marginalised students in schools, a number of studies report on marginalised students in elite higher education institutions. Granfield's (1991) study reports on how marginalised students studying law at an American university considered themselves as "cultural outsiders" and as such describe experiencing significantly high levels of anxiety about their academic and social adequacy (p. 127). In order to manage the situation, Granfield (1991) reported that the students employed a strategy that he referred to as "appearance management" whereby the students successfully "mimicked their more privileged counterparts" (p. 129). By 'looking the part', the working class students felt that they were better equipped to fulfil the expectations of their status as elite lawyers and found themselves more likely to be welcomed into the profession.

A study by Reay, Crozier and Clayton (2009) describes how working-class students navigated an elite university context and highlights the complex interplay between the students' 
backgrounds, their personal dispositions, and the educational environment that impacted on the degree to which the students adopted learning identities within the higher education setting. The authors argue that the students' ability to adjust to the academic and social demands of an elite university depended on them developing a particular habitus (see Bourdieu \& Passeron, 1977) that aligned with the institutional habitus of the elite university.

Studies that outline the challenges experienced by marginalised students in a higher education institution within the context of post-apartheid South Africa (see for example Hobden \& Hobden, 2015; Pym \& Sacks, 2017; Watson et al., 2009) report similar findings. Watson, Nind, Humphris, and Borthwick (2009) argue that the challenges faced by marginalised students in the transition from school to university "stem from its [the university's] long-established culture, which generally remains oriented towards the traditional white middle-class student population." (p. 666) The authors further highlight that both energy and identity work is required from marginalised students who do not possess the institutional capital or habitus to navigate the higher educational field with ease.

Before moving to the data presentation and discussion, we present an outline of the research study design. This section includes a discussion on the research participants who were interviewed for the study.

\section{Research Design}

The study makes use of a qualitative experience-centred narrative enquiry acquired using individual semi-structured interviews. The focus of the interview questions was on the students' reflective accounts of their experience of the application and selection process for the scholarship; their entry into, and experience of the elite school environment; what they considered to be the benefits as well as the challenges of attending an elite school coming from 
a disadvantaged background; and, on reflection, what advice would they give to other students who are considering applying for scholarships to attend elite secondary schools.

As authors, and like many other qualitative-oriented researchers, we view the act of research as being far from value-free (Denzin and Lincoln, 2011). Qualitative researchers stress the socially constructed nature of reality and the intimate relationship between the researcher and what is studied, and the situational constraints that shape inquiry (Golafshani, 2003). Further, as Thomson (2017) emphasises, “no knowledge, no know-how and no 'truth' however 'scientifically' produced - can be taken for granted, including the researcher's own knowledge" (p. 47). Given this, as white, middle-class, English-speaking South Africans, both of whom whose teaching and management careers have been located within the elite school field, we took care throughout the research process to adopt a reflexive attitude towards our research practices, reflecting upon how forces such as our social and cultural background and position within the elite school field may influence possible conscious and unconscious bias arising from these factors. Steps that were taken to mitigate these issues included, amongst others, recruiting participants through an anonymous questionnaire sent to students identified as possible research participants; establishing a rapport with the participants prior to the interview via emails or WhatsApp to respond to any of their questions about the research and interview process and gain the trust of the participants; and ensuring that the participants understood the authors' position as researchers who were not connected to any of the scholarship foundations or schools they attended to mitigate any possible power relations within the interview process. The narrative enquiry research approach was used as it allows for the possibility of seeing "different, and sometimes contradictory layers of meaning, to bring them into useful dialogue with each other, and to understand more about individual and social change" (Andrews et al., 2008, p. 1). Connelly and Clandinin (1990) state that narrative, as lived and told stories, is a way of organising human experience. 
In order to analyse the data, an inductive thematic narrative analysis was used. In thematic narrative analysis, the researcher presents the participants' personal experiences by establishing various themes that are highlighted across the different narratives presented. The inductive approach was applied as the research focus was on gathering the narrative experiences of the participants to find themes or similarities to explore the personal and social aspects of the participants' experiences as scholarship students in elite school contexts. The students who were part of the study were all former scholarship students from disadvantaged backgrounds between the ages of 19 and 24 years who attended fourteen different elite South African secondary schools as the recipient of a full scholarship awarded in their Grade 7 year. Two donor foundations were chosen from which to draw the sample of participants for the study. Foundation 1 operates on a national scale, with partner schools in four of South Africa's nine provinces, and Foundation 2 operates exclusively with schools based in Cape Town. The schools that the scholarship students attended are determined by the two donor foundations and include girls and boys-only schools as well as co-educational schools.

The criteria for the awarding of a scholarship are determined by the donor foundations and almost exclusively include the conditions of 'historically disadvantaged' and 'demonstrated financial need' as their starting points for the application and selection process. Twenty participants were invited to be part of the study, 10 students from each foundation and almost an even split between females (11) and males (9). The racial profile, according to their self-classification was 14 African, 1 Indian and 5 coloured participants. Although not one of the selection criteria, since leaving school all of the participants had enrolled in tertiary institutions.

Ethical clearance for the research project was granted by the relevant higher education institute and the participants all gave formal consent for the interview data to be used. Pseudonyms have been used for all the research participants, the foundations are referred to as 
Foundation 1 and 2, and no specific schools are mentioned to ensure confidentiality of the research process.

\section{Discussion}

A central theme that emerged from the interview data, and that links to many of the research findings in the studies presented above, was that the students felt that they had to change in order to fit into the elite school field. While many of these changes were initially tough to endure and make, the student data reflects that most of the students felt that it was a necessary and worthwhile endeavour as it enabled them to fit in and develop a sense of belonging in the elite school context.

\section{Embodying change}

Most of the students tried to identify what they felt had changed from their involvement in the elite schooling environment:

I feel like [School A] has made me. Like, the way I speak is [School A], the way I behave, the way I know how to be professional. And I know how to be positive. ... And it's not like you're putting up a front in some way, but I feel like they just kind of build you up to be this kind of person. (Yolande)

Something I've gained is being a powerful woman. I look at Facebook and Twitter and everything, and I look at all the women who were in my grade, and ... every single one of them illustrates or demonstrates mannerisms of a powerful woman. (Amanda) 
Although Amanda doesn't specifically define what she believes these mannerisms to be, it is evident that she views the qualities associated with them in a positive light, and embraces them as a part of who she feels she has become.

Siyabonga, struggling to articulate precisely what it is that he felt that he had acquired, states that he thinks that all students who attended his elite school, regardless of their socioeconomic background, are different:

Even though you might not have money [as a scholarship student], you'll still have a certain quality because you're a [School B] boy, and that just permeates through all interactions.

Similarly, Yusef notes:

If I look as a whole at the people coming out of [elite] schools ... and I look at the other people [at university], you can see the difference automatically. I mean, it's weird, but the way you assert yourself ... it's just easier. The way you ... carry yourself. Your whole body language. Like, you can spot the difference, even though it's slight.

Discussing what he noticed between himself and his friends at university who did not attend an elite school, Yusef states:

I think their interaction with people from different cultures, backgrounds and races is not as rich as mine. Like, I wouldn't be afraid just to walk up to anyone and start a conversation with them, whereas they don't. Like, basically from my primary school I used to have this whole fear, and they are still having that now. When they come into university they are experiencing what I experienced in Grade 8, now. 
This sense of confidence and ease in the university space that Yusef describes can be equated with Khan's (2011) findings in his study on adolescents elite in a prestigious secondary school in the United States of America. Khan (2011) describes these students as possessing an "ease of privilege", a quality that he concludes is a form of embodied knowledge that students who are exposed to an elite environment for a prolonged period of time learn, and that allows them to act comfortably in the world across a diverse set of social situations (p. 77). Similarly, Koh and Kenway (2012) assert that a feature of elite schools is that the students display a certain "eloquence and poise" (p. 333), and Forbes and Lingard (2013) highlight a "distinctive demeanour" that they observed in the students of their study that they describe as "an affect, or capacity to act of 'assured optimism"' (p. 51).

Embodying change did not just involve shifts to the participants' physical demeanour; it also involved mental shifts in terms of a broadening of their outlook that they gained as a consequence of attending an elite school. Natasha describes this as coming to realise that "the world has so many different fragments within; it's not just the world I thought there was." Likewise, Jamal believes that if he "wasn't exposed to that whole new world", he would still be "stuck with my primary school friends ... with the same box-mentality." He notes that he now recognises that "my normal is not everyone's normal." Amirah believes that it was being exposed to new things and opportunities provided by the secondary school she attended that has changed her. She describes herself as now feeling less "stagnant ... in a way I feel less typical, I feel like I've actually done something different."

Likewise, both John and Mandla felt that they developed a far broader outlook on the world from their engagement with the elite school. John described how he feels that he now has "a more global outlook" that has resulted in him "chang[ing] the way I look at simple things, like how the economy is doing, and is it feasible, and such and such." Mandla stated 
that since attending the elite school he feels his world has extended beyond that of the township where he grew up, “where you see yourself as so limited ... you don't know what the world out there has, and how big it can be ... my horizons [are] broader and I want more; I want more out of life."

\section{Family and community: new ways of being}

A number of students described how they felt that attending an elite school had changed them and the impact of this on their family and friends. Koketso stated that his family and community felt he had changed, to the extent that he feels that he is now treated as a foreigner at home due to him spending "five years only speaking English to people" as a boarder in secondary school:

So when I came back to North West [Province] people thought that I was from outside South Africa. My vocabulary wasn't the same as theirs. People thought I speak another language. The way they treat me [is] like ... I'm an outsider.

Koketso also felt that people within his community think that he is "arrogant ... [as I] tried to get better by going away to a good school." Now he feels that he has to change the way that he speaks English when he is at home: "To make sure that I communicate with most people I have to 'ham it down' and speak in simple English, speak slowly. ... I change [my] vernacular to fit in at home."

Similarly, Mandla feels that he is seen as being different by his friends:

The very first time I came back [home] I could feel nothing was the same. ... The relationships and how people treated me ... changed. Because now my friends were like: 'You think you're better because you go to this school.' ... No matter how hard I tried to be, 'Guys, it's still me, it's still me!' You know, we lost levels of relatability. 
Reflecting back Mandla recognises that he had changed in relation to his peer group in his community:

Our ambitions ... which I think was the biggest cause of drifting apart. ... I say all this in retrospect. I'd gone to this school and now ... I want more out of life. When I got back home and I said, 'This is what I want to do', my friends were like, 'What!' You know, I seemed ... I guess I started to seem foreign to them.

John also used the word "foreign" to describe the sense of distance that he now feels between himself and the community in which he grew up. He attributes this to not only attending a different school to his primary school peers but also due to the fact that he chose to become a full-time boarder over the five year period that he attended his school:

It sometimes feels foreign. I mean if I walk around the area that I lived in, I literally know no one. I just walk around and people are like, 'Oh, you're the little brother.' So I feel that it is foreign for me, being in my parents' area.

John further states that "the main cost of schooling, especially in my context, was my relationship with my family." John describes himself as living "a bipartite life" between his family and community, and his school and now adult life. Similarly, Siyabonga noted: "I constantly [felt] a diaspora, so to speak, between my home life and my school life". Even though Siyabonga's secondary school was close to his family's home he decided to become a weekly boarder and often chose to stay at school over the weekends:

Even though I lived close [a township that is a 10 to 15 -minute drive from the school], it wasn't always practical [to go home] because I was involved in a lot of things [at school]. So I was away from home for most of my [secondary school] life, and so my personality shifted here and there. You don't notice 
these things because you don't have that mirror. Because if it shifts it means you're assimilating, or it means that you're becoming one of them.

While most of the students considered the changes in themselves as a positive consequence of attending an elite school, Siyabonga was not entirely comfortable with how he felt his life had changed as he regarded the changes as a form of betrayal to who he was before attending the elite school, and how he was raised by his mother.

A significant aspect for Amirah and her family was related to her decision in primary school to start wearing a hijab. During her primary school years, she was permitted to wear it as a part of her school uniform. However, the secondary school she attended as a scholarship student did not allow her to wear her hijab as a part of the school uniform. In Grade 10 Amirah made the decision to stop wearing her hijab altogether. She narrates what transpired:

When I stopped wearing it, everyone went bonkers. They were like, 'Ja [yes], it's because of this white school', and ... 'This is what these people do.' ... And I was like, 'I'm not going to explain to you the reason. I have the reason why I stopped wearing it, but it's not because of the school.' I knew that it had nothing to do with the school. But they wouldn't leave it: 'It was the white people that told you to stop wearing your scarf on your head!'

Amirah described this period as "... very difficult ... I think that it was one of the most challenging things." Amirah's family felt that her decision to stop wearing a hijab in Grade 10 was a form of betrayal and they viewed it as "giving in" to the expectations of the cultural norms of what they described as the 'white' elite school field. Even though Amirah protests that this was not the case, her family viewed this decision in a negative light and felt that the school had changed her. 
Natasha, Thabo and Amanda also discussed the extent to which they felt that they had changed.

Natasha, for example, stated that she no longer sees her extended family:

When I was younger I used to interact with them more. But then once I went to high school ... I have lost connection with them. ... We are just very different now.

Although Thabo still lives with his family in the township where he grew up, he no longer regards this as his home:

Home to me now? University is where I would call home because I spend most of my time in [he names two formerly whites-only, mainly middle-class suburbs in Cape Town]. It's where my friends are. In the morning I take a taxi and go to my friends, before heading to university.

Amanda has chosen to distance herself from her family and lives on her own:

I've become more powerful and more questioning. I don't do things that most young black women would do. You know, my father's a priest ... and my mom is a very religious woman, and so that patriarchal kind of vibe is there, and I'm not about that. And so sometimes that causes a lot of conflict [as] I question things. I'll ask why. I'll decide that I don't want to do it. I'm challenging. My siblings are not like that, and they're like, 'Oh she's rude.' ... I think I can sometimes be considered a problematic child or a challenging one, [and] that's a negative aspect. I now live alone; they don't really see me much.

Natasha reflecting on changes in herself from her experience as a scholarship student stated: "I'm looking back at the person I have become because of [School C], I'm not unhappy with 
that person, I didn't change, I just know different combinations [of myself] now, I let my roots grow, essentially."

\section{'Capital' gained}

Many of the students during the interviews were keen to describe what they regarded as the advantages of having attended an elite school in terms of the benefits that they are now experiencing as young adults. These benefits largely relate to their academic preparedness for tertiary studies, along with the gains that some of them feel that have acquired through their association with their school's good reputation and their automatic membership of a professional network of alumni.

Amanda, for instance, is deeply appreciative of "the way of learning" that she imbibed whilst at school, as she feels that this has ensured that in lectures at university "academically, you are much more prepared than anyone else ... [and I am able] to thrive actually, at university". These sentiments were echoed by Yusef:

I think, academically, you are much more prepared than anyone else ... [with] your schooling and your way of learning ... it's so much easier for you just to slot in ... the high school experience that I had allowed me to thrive at university.

Likewise, Yolande recognises that she was taught specific academic skills that not all students were taught:

When I'm sitting with ... kids in my class [they] ask me for certain things like, 'Can you help me do my essay? Can you do this?' It's because I feel like [School A] people paid so much attention to those sort of things. Even a simple thing such as referencing, and at university where everyone is supposed to 
know [how to reference]. And they will be like, 'We never did this at high school!' And I'm like, 'I did it for years; I know this!' And our research skills ... we did a research paper in Grade 11 and some kids are like, 'We have never heard of that before!' So in a lot of ways it definitely has prepared me for university ... and I feel like I wouldn't have gotten that if I was at a normal public school.

Lebo feels that by attending an elite school she was taught to "be consistent and work hard" which has assisted her in her university studies. Likewise, Jordyn credits her secondary school for her "work ethic" that has enabled her to achieve success in her tertiary studies where she is currently completing a specialised engineering degree.

In addition to feeling well-prepared for tertiary studies, some of the participants mentioned the social capital that they have accumulated from being associated with an elite school. Lebo, for example, stated:

[Foundation 1], [School D] - have created names for themselves and have a good reputation, and the minute you're associated with [them], you become part of that name. Yeah, having both factors on my CV is great because most people will go like, 'Oh, you were at [School D]! Oh, you were a part of [Foundation 1]!'

Yolande notes that she has discovered that there are benefits to mentioning that she went to School A when applying for part-time jobs: "Because I feel like everyone has this huge expectation of what a [School A] girl is like and what they have achieved." She notes that every time she mentions the school that she went to in an interview, "I got the job!" 
Mandla acknowledges that he hasn't hesitated to use the "good name" of his school to his advantage. He is now a part of a Chartered Accountant programme of a well-known finance corporation and notes:

In my first year I had my [School E] Old Boys tie on, and you will be amazed: 'Oh my gosh! Are you a [School E] Boy! Are you [Foundation 1]!' So many networks that I've made. ... 'And this is why we need to work as a network.' That is what they always say.

John described how he came to realise the benefits associated with being part of an old boy's alumni:

I have heard many stories of people saying that 'Hey, we are from [School F]' [and] then all of a sudden jobs have opened because of being of the boys' school. And that's the largest thing about being part of these old boys' schools - once you are part of the association there are just endless opportunities.

Bongani notes that he has already had an opportunity to take advantage of these connections as a second-year actuarial science student:

This last vac I worked at [a large investment company] ... and the way that I got that vacation work is that I approached an actuary who also went to [School G] ... I emailed him and told him who I am ... and I told him that I went to [School G]. And through that ... he told me of the vac work at [the investment company]. And more than that he was going to send his contact details to his friends who are also actuaries, and ... one of them was the CEO of a company in Joburg, and we met just to, like, bounce off some ideas ... and he was telling me his journey and I was telling him my journey. 
Likewise, Yusef related an experience when he did some "vac work" for the accounting firm that is funding his degree. As a part of this experience, he was sent to complete an audit,

with two trainees about to qualify as CA's, [and one of them was] a [School $\mathrm{H}]$ boy. So, automatically you feel this ease and connection ... they have also been through experiences that you know you have also been through. And so the whole relationship with him is so much easier than having someone who you have no past experiences with.

The benefits and opportunities that the students are describing are forms of social and cultural capital. All of these students refer to aspects of social relationships, interactions, networks and relationships such as alumni networks, which form part of the social capital that they feel they have accumulated as a result of being associated with an elite school. Cultural capital, as a form of symbolic capital, is found in the students' reference to culturally significant attributes that they came to recognise that the field of elite schooling has provided them. Discussing aspects of social capital, Bourdieu (1986) notes that

$[t]$ he volume of social capital possessed by a given agent ... depends on the size of the network of connections he can effectively mobilize and on the volume of the capital (economic, cultural or symbolic) possessed in his own right by each of those to whom he is connected. (p. 21)

Thus, what Bourdieu is stating is that the existence of a network of connections is not a natural or social given; rather it is the product of an endless effort of an institution which enables the individuals associated with the institution to produce and reproduce significant relationships. These relationships may, over time, secure them additional material or symbolic (cultural capital) profits (Bourdieu, 1986). 


\section{Effects and consequences}

For most of the participants in this study, as discussed above, they regarded the opportunity to attend an elite school as placing them in an advantageous position in terms of their tertiary studies and future work prospects. At the same time, however, some students described the personal impact of being a scholarship student at an elite school:

At the end of the day, they gifted us an opportunity, but they still hurt us. Because most of the scholars that I have spoken to still have a lot of unresolved emotional as well as mental issues. So you're sacrificing your emotional and your mental health to have the opportunity to grow in terms of knowledge and exposure to different types of intelligences. Which I appreciate, but ... I still regret not having somebody tell me that your mental or your emotional health is important. (Siyabonga)

Siyabonga continued by describing how he became an insomniac in his final year at school as he felt so much pressure to perform academically, as well as maintain his involvement in other areas of the school, in a continuous cycle that he described as "give and take, give and take." Ultimately, he felt that this existence was unsustainable and he stated that in his first year of university, "it all came crashing down and I couldn't even get out of bed."

Similarly, Khanyiswa, in considering whether or not she would one day be prepared to send her own daughter to the same secondary school that she attended, initially referred to herself as "a survivor", but one who "still has scars ... [as] in high school you were assimilating to white girls, you were assimilating to 'that thing'. And it was very violent."

Looking back, Thabo identified "kinds of struggles" that he feels he faced during his secondary schooling: 
Me being a scholarship kid made people look at me in a different way. It's not like you can afford to be at the school. They will like, 'Okay, you're poor, and because of the scholarship, that's why you are here.' ... I remember looking at it when I was in class, and people will be seen as, 'They are so-and-so's daughter' and 'So-and-so's son.' And when they came to me, they will be like, 'Oh, this is the scholarship kid.'

For others, like Natasha and Mandla, they recognised that the scholarship changed the course of their lives fundamentally:

If I didn't get the scholarship, I don't know where I would be right now. ... I don't know if I would have gone to high school. (Natasha)

Those [Foundation 1] forms changed the direction of my life. Now, imagine my life trajectory, I don't know.... My horizons, as a result of [the Foundation 1 scholarship], got so much bigger. I saw so much more in myself than what I could actually ever. (Mandla)

Jordyn also recognised that her life might have turned out very differently if it hadn't been for the scholarship:

'Cos the scholarship definitely made me feel ... not that I needed to prove myself, but I needed to work hard for them, and I needed to kind of uphold that. They saw something in me, so there must be, you know? It must mean something. [I] could have easily turned in the wrong direction. I could have rebelled against my family, my parents. But I never once felt that way, you know. I always felt like I had a responsibility to do well still. 
Yusef expressed appreciation for how the scholarship benefitted him saying "you go to class, the teachers teach well, you go home, you work, you write the exams, you do well”.

Given all of this, what is evident through the reflective accounts of the scholarship students, is that the giving of a scholarship involves a complexity of experiences for the students and involves costs and benefits, neither of which are the same for each student nor can be easily quantified. As stated by Kuriloff and Reichert (2003) in their study, it is suggested that schools and donors can learn from the way in which the scholarship students' accounts of their experiences, in order to devise strategies to support all their students to develop a sense of belonging in their schooling context. Many of the students acknowledge that their initial encounter with the elite school context - what Reay et al (2009) refers to as the "shock of the elite" - took time, energy, emotion and effort to manage (p. 1110). However, most of the participants in this study stated that given the choice again, they would not change their decision to accept a scholarship to attend an elite school.

\section{Concluding reflection}

One of the possible questions that arise from a study of this nature is what the long-term impact of accepting a scholarship will be. To conclude we end with an extract from Kelly's interview who, at the time of the interview was a 21-year university student studying Bachelor of Science Speech-Language Pathology at University. Kelly, towards the end of the interview, reflected what she believed receiving a scholarship meant for her and other scholarship students.

I have the voice from the scholarship. I have the education. Basically, I have the English to talk to people who are in management positions and be like, "Look, this is what's wrong", that some other students who feel as strongly about the movement might not have. They just don't have the voice. ... The reality is the majority of the [Higher Education Institute that she attends] 
board are white people. Our vice-chancellor is white, so you're not gonna go there and speak Xhosa or Setswana or Venda. You're gonna have to address him in English so that he can hear you. ... So scholarship students have that they have the education. But more than having the education ... they have the marks, so they can't be labelled as lazy. They can't be labelled as wanting things that they haven't worked hard for.

I'm on campus, and I'm getting straight A's, but my mom can't afford it ... My university costs around R160 000 in total. It is a lot of money. ... I don't think cleaners earn more than, say, R4 000. So, we're children who come from disadvantaged backgrounds, and we understand the struggle. ... The only difference is that the other [black] students don't have that voice in terms of language and the way they carry themselves. The reality is growing up in the townships you need to fight. ... If you grow up having to fight for everything that you have, it's how you gonna ask for things when you become an adult. You're always going to fight for the things that you want, and that's your attitude that's going to come forward. But we go to [School H], and we're taught to be ladies and well-mannered, so we can sit in meetings and be wellmannered and be calm, and not maybe be loud the way people might see other people. The thing is that scholarship students know the struggle and they just have that added extra of being, "Okay, I can conduct myself in the manner that is required." ... But we understand the struggle because we come from it. We come from mothers who have to work two jobs, we come from mothers who struggle to make ends meet. So we have the voice but we also have the struggle, which makes it easier for us to be the movement. 


\section{References}

Andrews, M., Squire, C., \& Tamboukou, M. (2008). Doing Narrative Research (M. Andrews, C. Squire, \& M. Tamboukou (eds.). Sage Publishers.

Bloch, G. (2009). The Toxic Mix: What's wrong with South Africa's schools and how to fix it. Tafelberg.

Bourdieu, P. (1986). The Forms of Capital. In J. Richardson (Ed.), Handbook of Theory and Research for the Sociology of Education. Greenwood.

Bourdieu, P., \& Passeron, J.-C. (1977). Reproduction in Education, Society and Culture. Sage Publishers.

Connelly, F. M., \& Clandinin, D. J. (1990). Stories of experience and narrative enquiry. Educational Researcher, 19(4), 2-14.

Denzin, N., \& Lincoln, Y. (2011) (Eds.) The SAGE Handbook of Qualitative Research. Thousand Oaks, CA: Sage. Dolby, N. (2001). Constructing Race: Youth, Identity and Popular Culture in South Africa. State University of New York Press.

Epstein, D. (2014). Race-ing class ladies: lineages of privilege in an elite South African school. Globalisation, Societies and Education, 12(2), 244-261.

Fataar, A. (2007). Schooling, youth adaptation, and translocal citizenship across the postapartheid city. Journal of Education.

Fataar, A. (2015). Engaging Schooling Subjectivities: Across Post-Apartheid Urban Spaces. SUN MeDIA.

Forbes, J., \& Lingard, B. (2013). Elite School Capitals and Girls' Schooling: Understanding 
the (Re)production of Privilege through a Habitus of 'Assuredness.' In C. Maxwell \& P. Aggleton (Eds.), Privilege, Agency and Affect. Palgrave Macmillan.

Geyer, K., \& Walton, E. (2015). Schooling in the Shadow of Benevolence: the Experience of Scholarship Recipients in Affluent Schools. South African Journal of Higher Education, 29(1), 335-353.

Giroux, H. (1983). Theory and resistance in education. Bergin and Garvey Publishers.

Golafshani, N. (2003). Understanding Reliability and Validity in Qualitative Research. The Qualitative Report, 8(4), 597-607.

Granfield, R. (1991). Making it by Faking it: Working Class Students in an Elite Academic Environment. Journal of Contemporary Ethnography, 20(3), 331-351. https://doi.org/10.1177/089124191020003005

Hobden, S., \& Hobden, P. (2015). A study of the transition pathways of school level scholarship recipients into work and tertiary education. South African Journal of Education, 35(3). https://doi.org/10.15700/saje.v35n3a1054

Hofmeyr, J., \& Govender, R. (2015). South African Reconciliation Barometer 2015: Briefing Paper 1 .

Horvat, E. M., \& Antonio, A. L. (1999). “Hey, Those Shoes Are Out of Uniform”: African American Girls in an Elite High School and the Importance of Habitus. Anthropology and Education Quarterly, 30(3), 317-342.

Kenway, J., \& Fahey, J. (2015). The gift economy of elite schooling: the changing contours and contradictions of privileged benefaction. British Journal of Sociology of Education, $36(1), 95-115$. 
Khan, S. (2011). Privilege: The Making of an Adolescent Elite at St. Paul's School. Princeton University Press.

Koh, A., \& Kenway, J. (2012). Cultivating national leaders in an elite school: deploying the transnational in the national interest. International Studies in Sociology of Education, 22(4), 333-351.

Kramer, R. (2008). Diversifiers at Elite Schools. Du Bois Review, 5(2), 287-307. https://doi.org/10.1017/S1742058X0808017X

Kuriloff, P., \& Reichert, M. C. (2003). Boys of Class, Boys of Color: Negotiating the Academic and Social Geography of an Elite Independent School. Journal of Social Issues, 59(4), 751-769.

Lemon, A., \& Battersby-Lennard, J. (2011). Studying together, living apart: Emerging geographies of school attendance in post-apartheid Cape Town. African Affairs, 110(438), 97-120. https://doi.org/10.1093/afraf/adq062

Mills, C., \& Gale, T. (2010). Schooling in disadvantaged communities: Playing the game from the back of the field. Springer.

Pym, J., \& Sacks, J. (2017). The Impact of Previous Experiences and Social Connectedness on Students' Transition to Higher Education. In B. Bongeni \& R. Kapp (Eds.), Negotiating Learning and Identity in Higher Education: Access, Persistence and Retention (pp. 155-179). Bloomsbury Academic.

Reay, D., Crozier, I. G., \& Clayton, I. J. (2009). "Strangers in Paradise”? Working-class Students in Elite Universities. Sociology, 43(6), 1103-1121.

Simpson, A. (2012). Adolescent identity experiences of historically disadvantaged 
scholarship recipients attending independent South African high schools. Stellenbosch University.

Slee, R. (2011). The Irregular School. Routledge.

Soudien, C. (2007). Youth Identity in Contemporary South Africa: Race, Culture and Schooling. New Africa Books.

Soudien, C. (2008). Report of the Ministerial Committee on Transformation and Social Cohesion and the elimination of discrimination in public higher education institutions.

Soudien, C. (2012). Realising the dream: Unlearning the logic of race in the South African school. HSRC Press.

Spaull, N. (2013). South Africa's Education Crisis: The quality of education in South Africa 1994-2011. https://doi.org/10.1007/BF03217477

Taylor, N., Fleisch, B., \& Shindler, J. (2008). Changes in education since 1994. Higher Education, 32(February), 3-5.

The World Bank. (2018). Overcoming Poverty and Inequality in South Africa: An Assessment of Drivers, Constraints and Opportunities. doi: 10.1596/29614.

Thomson, P. (2017). Educational Leadership and Pierre Bourdieu. London: Routledge.

Watson, J., Nind, M., Humphris, D., \& Borthwick, A. (2009). Strange New World: Applying a Bourdieuian Lens to Understanding Early Student Experiences in Higher Education. British Journal of Sociology of Education, 30(6), 665-681. 